\title{
TREATMENT OF ANEJACULATION IN THE TOTAL PARAPLEGIC BY SUBCUTANEOUS INJECTION OF PHYSOSTIGMINE
}

\author{
By P.-A. Chapelle ${ }^{1}$, F. Blanguart ${ }^{1}$, A. J. PueCh ${ }^{2}$ and J.-P. Held
}

${ }^{1}$ Chaire de Clinique de Rééducation Motrice, Hôpital R. Poincaré 92380 Garches, France. ${ }^{2}$ Département de Pharmacologie Clinique, Groupe Hospitalier PitiéSalpêtrière, 47-83, bd de l'Hôpital, 75013 Paris, France.

Summary. The authors describe a new therapy for paraplegic anejaculation.

Sub-cutaneous injection of Physostigmine with certain precautions and with selected methods of application can be used for patients where there is the same indication for the use of an intrathecal injection of Neostigmine. The Tr2-L2 myelomeres must be intact. The new treatment is easier to perform, and when the patient has experimented with three tests in our hospital without any problems, he is granted permission to apply this treatment at home, without any medical supervision.

Key words: Paraplegic; Ejaculation; Physostigmine-subcutaneous injections.

\section{Introduction}

IN I949, Guttmann described a new way to treat paraplegic anejaculation: intraspinal injection of neostigmine (ISN) (Guttmann, I949). Several studies have been carried out since then including attempts to assess paraplegic fertility (Guttmann \& Walsh, I97I), to define as precisely as possible the indications of this technique (Chapelle et al., 1974). Other types of treatment have been described in order to avoid the most important side effect of the technique, that is, Autonomic Hyperreflexia (AHR), including electric masturbation (Tarabulcy, I972) or electro-ejaculation provoked by an intrarectal probe (François et al. 1978).

This work was undertaken in an attempt to find a pharmacological agent which would replace ISN; which would be easier to administer and and which would have no side effects.

\section{Working Hypothesis}

Neostigmine is an indirect parasympathomimetic agent which reversibly antagonizes acetylcholine esterase. Since it does not cross the blood brain barrier, it must be administered in situ by lumbar puncture to produce ejaculation. Physostigmine is also a reversible acetylcholine esterase antagonist, but it can transverse the blood brain barrier, and can thus be administered parenterally, for example by subcutaneous injection. However the general parasympathomimetic effect of the drug becomes a problem. By analogy, with the treatment of parkinsonism, it seemed logical to

Request for reprints: Dr Chapelle, Centre Saint-François, I480o Deauville, France. 
administer at the same time an inhibitor of the peripheral parasympathetic system (or its peripheral effectors). N-buthylhyocine bromide was used for this purpose, thus permitting the central action of physostigmine, whilst eliminating its disagreable peripheral effects (nausea, vomiting).

The subjects chosen were men between I 8 and 50 years of age with traumatic paraplegia present for at least six months (in order to assure neurological stabilisation), with a clinical syndrome of complete spinal cord section. Patients who had undergone treatment which would affect the neuro-muscular urogenital system, even temporarily, were excluded from the study.

\section{Method}

A clinical neurological examination, described in detail elsewhere (Grossiord et al., I 978) was performed to determine the extent of the syndrome, affecting both the somatic (cerebrospinal) and vegetative (ortho and parasympathetic, in the anatomical sense) systems (Chapelle, I978).

Every patient was initially treated with physostigmine (PSC).

Several weeks later the same patients received either intraspinal neostigmine (especially when the first treatment failed), or a second dose of physostigmine (especially when the first treatment was successful). As we have previously shown, ISN can only be effective when the TI2, Li and L2 myelomeres are not involved. (Chapelle, I974; Chapelle, I982). We did not systematically perform the ISN test when the lesion affected segments TI2, $\mathrm{L}_{\mathrm{I}}$ or $\mathrm{L}_{2}$ and the PSC test was negative. Patients were required to fast for at least 12 hours, and have an empty bladder.

In the ISN test, after lumbar puncture was done, 0.25 or $0.5 \mathrm{mg}$ of neostigmine were mixed with cerebrospinal fluid and injected intrathecally; masturbation began 30 minutes later.

In the PSC test, $2 \mathrm{mg}$ of physostigmine sulfate was injected subcutaneously 30 minutes after $\mathrm{N}$-buthylhyocine $40 \mathrm{mg}$ was given. Masturbation began I 5 minutes later. If no result was obtained, some patients received a supplementary injection of I $\mathrm{mg}$ of physostigmine 30 minutes after the first injection. If side-effects appeared during the ISN or PSC test, the patient was asked to stop masturbation. After verification that the bladder was empty, metoclopramide ( $10 \mathrm{mg}$ ) was injected subcutaneously, (sometimes in association with an intravenous injection of $0.25 \mathrm{mg}$ atropine).

The PSC test was always performed by the same nurse who was uninformed as to the nature of the product injected for the result expected a priori, but who told the patient that every test would be successful. This precaution seemed to be a non-neglibible criterion of good faith in the experiment which the nurse fully accepted.

The tests were considered positive if ejaculation occurred and spermatozoa were present in the ejaculate.

\section{Results}

The results are summarized in Table I. The first PSC test was successful in five of the 20 patients. Three patients (numbers 7, 8 and I 5) were successful in subsequent tests. Twelve remained unsuccessful. 
TABLE I

Results of the subcutaneous physostigmine tests

\begin{tabular}{|c|c|c|c|c|c|c|}
\hline \multirow[t]{2}{*}{ Patients } & \multicolumn{2}{|c|}{ U.L.L.S. } & \multirow[t]{2}{*}{ L.L.L.S. } & \multirow{2}{*}{$\begin{array}{c}\text { Ist } \\
\text { S.C.P. }\end{array}$} & \multirow[t]{2}{*}{ I.S.N. } & \multirow{2}{*}{$\begin{array}{l}\text { Next } \\
\text { S.C.P. }\end{array}$} \\
\hline & Sensory & Motor & & & & \\
\hline I & $(\mathrm{T} 6) \mathrm{T}_{7}$ & T6 & $\mathrm{T} 8$ & success & & success \\
\hline 2 & $\left(T_{I} 2\right) L_{I}$ & $\mathrm{~T}_{\mathrm{I} 2}$ & $\mathrm{~L}_{3}$ & failure & failure & \\
\hline 3 & $\left(T_{I I}\right) T_{I I}$ & $T_{I I}$ & $\mathrm{~S}_{5}$ & failure & failure & failure \\
\hline 4 & $(\mathrm{~T} 2) \mathrm{T} 6$ & $(\mathrm{~T} 2) \mathrm{T} 6$ & TI2 & failure & failure & $\begin{array}{c}\text { ISN + } \\
\text { SCP } \\
\text { failure }\end{array}$ \\
\hline 5 & $\left(\mathrm{~T}_{7}\right) \mathrm{T}_{9}$ & $\mathrm{~T} 8$ & Tio & success & success & success \\
\hline 6 & $\mathrm{~T}_{9}$ & $\mathrm{~T}_{9}$ & $T_{I I}$ & success & & success \\
\hline 7 & $\left(\mathrm{~L}_{\mathrm{I}}\right) \mathrm{L}_{2}$ & $\left(\mathrm{~T}_{\mathrm{I}} 2\right) \mathrm{L}_{4}$ & $\mathrm{~S}_{5}$ & failure & success & success \\
\hline 8 & $\left(\mathrm{~T}_{5}\right) \mathrm{T} 6$ & $\left(\mathrm{~T}_{3}\right) \mathrm{T} 6$ & $\mathrm{~T} 8$ & $\begin{array}{l}\text { (vomiting) } \\
\text { failure }\end{array}$ & $\underset{\text { SCP }}{\text { ISN }+}$ & success \\
\hline 9 & $\left(\mathrm{~T}_{\mathrm{I}} 2\right) \mathrm{L}_{2}$ & $\left(\mathrm{~T}_{\mathrm{I}} \mathrm{I}\right) \mathrm{L}_{2}$ & $\mathrm{~L}_{5}\left(\mathrm{~S}_{2}\right)$ & $\begin{array}{c}\text { success } \\
\text { vomiting }\end{array}$ & $\begin{array}{l}\text { success } \\
\text { failure }\end{array}$ & \\
\hline IO & $\left(T_{I I}\right) L_{2}$ & $T_{I I}$ & $\mathrm{~S}_{5}$ & $\begin{array}{l}\text { (vomiting) } \\
\text { failure }\end{array}$ & failure & \\
\hline I I & (T9) TIo & $\mathrm{T}_{9}$ & $\mathrm{~L}_{2}$ & failure & failure & failure \\
\hline 12 & $\left(T_{I I}\right) T_{I 2}$ & TII & $\mathrm{S}_{2}$ & failure & failure & \\
\hline 13 & $\left(\mathrm{~T}_{\mathrm{I}} \mathrm{I}\right) \mathrm{L} 2$ & TI2 & $\mathrm{L}_{5}\left(\mathrm{~S}_{3}\right)$ & failure & failure & $\begin{array}{c}\text { ISN }+ \\
\text { failure }\end{array}$ \\
\hline I4 & $\left(T_{I 2}\right) L_{I}$ & $T_{I I}$ & $\mathrm{~L}_{\mathrm{I}}$ & success & & \\
\hline 15 & (T5) T8 & T6 & T9 & failure & success & success \\
\hline 16 & $(\mathrm{~L} 2) \mathrm{L}_{3}$ & $\mathrm{~L}_{\mathrm{I}}$ & $\mathrm{L} 4$ & failure & failure & $\underset{\text { SCP }}{\text { ISN }}$ \\
\hline & $\left(\mathrm{T}_{\mathrm{I}}\right) \mathrm{T}_{\mathrm{T}}$ & & $\mathrm{L}_{5}$ & failure & & $\begin{array}{l}\text { failure } \\
\text { failure }\end{array}$ \\
\hline I 8 & (T6) $\mathrm{T}_{7}$ & T6 & T9 & success & & \\
\hline I9 & $\left(T_{I I}\right) T_{I 2}$ & TII & $\mathrm{L} 4$ & $\begin{array}{l}\text { failure } \\
\text { vomiting }\end{array}$ & & failure \\
\hline 20 & $T_{12}$ & $T_{12}$ & $\mathrm{~L}_{\mathbf{I}}(\mathbf{L} \mathbf{2})$ & failure & failure & failure \\
\hline
\end{tabular}

U.L.L.S.: upper limit of the syndrome.

L.L.L.S.: lower limit of the syndrome.

Ist S.C.P.: first subcutaneous Physostigmine test.

I.S.N.: Intra spinal injection of Neostigmine.

(The levels in brackets are for those patients with an incomplete lesion).

Among the I4 patients undergoing the ISN test, four were tested by PSC associated with ISN with only one success. in Table II.

The results of the PSC test as a function of the syndrome are presented

I. In I I subjects, the lesion affected myelomeres TI2, LI, L2 (2, 3, 7, 9, IO, I I, I 2, I 3, I 7, I 9 and 20). In all cases the first PSC test was negative. Nine subjects underwent ISN tests (Patients 17 and I 9 did not undergo these tests since DI2, LI and L2 were totally affected). In eight cases the ISN test was negative. (Only Case 7 was positive and a subsequent PSC test was successful in this subject).

2. Among the three subjects with $\mathrm{D}_{12}, \mathrm{~L}_{1}$ and L2 lesions in which at 


\section{TABLE II}

The results of the cutaneous physostigmine tests in relation to the lesion

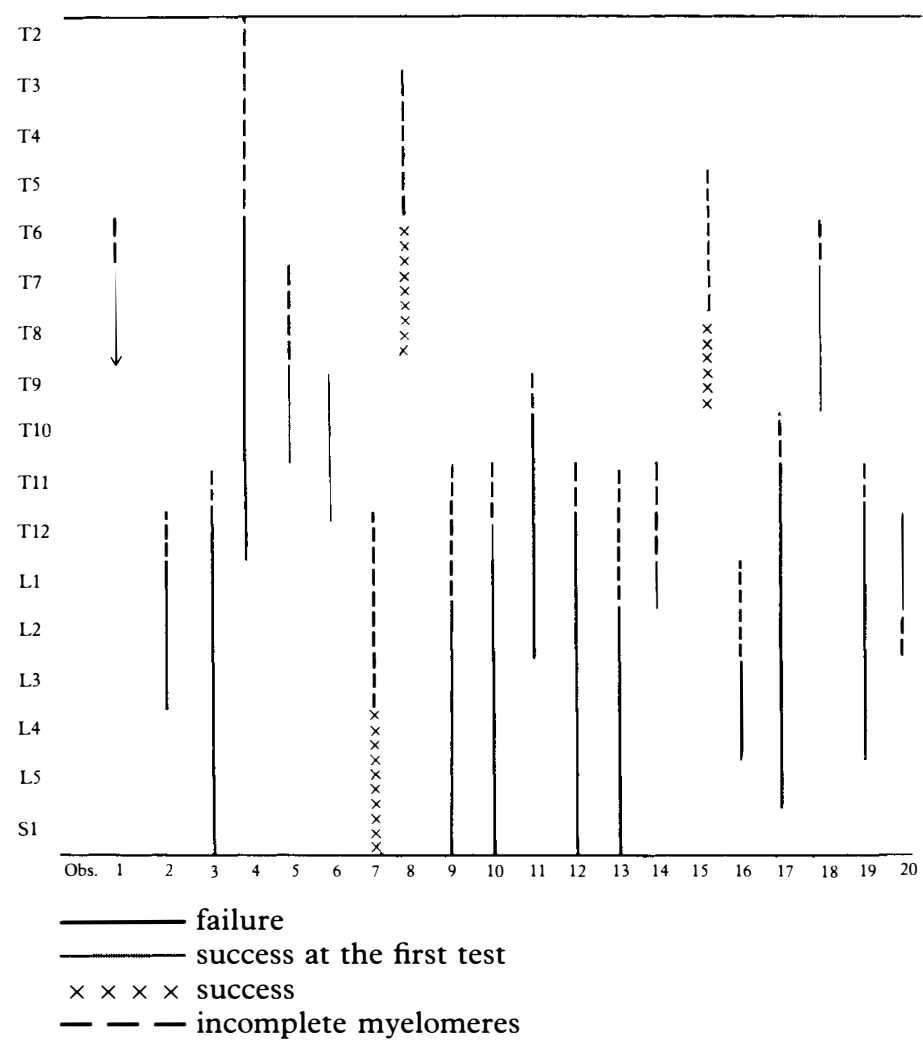

least one of the segments remained intact (Cases 4, I 4 and IO) two patients (4 and IO) had negative PSC test confirmed by a negative ISN test. The PSC test of the third patient (Case I4) was positive.

3. Among the six subjects in which the lesion did not affect $\mathrm{T}_{12}, \mathrm{~L}_{\mathrm{I}}$ and $\mathrm{L}_{2}$ (Cases I, 5, 6, 8, I 5 and I8). Four patients had positive results in the first PSC test, two of them did not undergo the ISN test. The other two patients ( 8 and I 5 ) had negative results with the first PSC, then positive results with the ISN and finally positive results with subsequent PSC tests.

\section{Discussion and comments}

I. The patients and their syndrome have been discussed.

If the lesion affected Di2, Li and L 2 myelomeres, both PSC and ISN tests failed. In the case of patient no. 4 whose lesion extended from T6 to $T_{12}$, both tests were also negative although a positive response could have expected. On the contrary, a positive PSC result was obtained with patient no. I 4, although a negative result was expected. The only explanation we can find for such an 'error' is that the clinical assessment of the spinal lesion was wrong. 
2. The PSC test is equivalent to ISN. Indeed, among the $\mathrm{I} 4$ subjects tested by both methods, the correlation was exact I I times on the first trial. In three cases (Cases 7, 8 and I 5), although the first PSC test was negative, the ISN test was positive as were subsequent PSC tests. The failure of patient no. 7 was probably due to vomiting which interrupted the trial. Patient no. 8, was discovered a posteriori, to have received $25 \mathrm{mg}$ of hexocycline methylsulfate (Traline) 3 hours before the first PSC test. No explanation has been found for the failure of patient no. I 5 in the first PSC trial.

In three patients, no. 4, I3 and I6, both tests (ISN and PSC) were associated because we tried to obtain an ejaculation by fair means or foul. Since all three attempts resulted in failure, we think the chances of provoking ejaculation are minimal, not to say inexistant, in the present state of our knowledge.

3. The indications for ISN and PSC tests are identical, but the latter presents fewer disadvantages. No autonomic hyperreflexia was observed during these tests either in this series of patients or among those patients who were not selected (we have tested about 90 cases at the present time). We thus felt authorized to encourage the patients to perform the test at home in the intimacy of their spouse.

The side effects of the tests are:

a. orthostatic hypotension, which always appears if strict decubitus is not respected, beginning 15 minutes after injection of physostigmine and continuing for 60 minutes. Tachycardia occurs during the test, but never exceeded I 40 per minute.

b. nausea is infrequent and occurs in one patient out of three at the moment of ejaculation.

c. vomiting only occurred 3 times (Cases 7, 9 and 19) in this series of 20 patients. But in one of these patients it occurred during each of the three tests and the test required to be interrupted. Such abnormal sensitivity to physostigmine seems (to us) to contra-indicate the ISN test.

d. other side effects were those related to premedication with anticholinergic agents (dryness of the mouth ...) and a sense of 'well being', 'floating in the space', and euphoria appearing about Io minutes after the injection of physostigmine, and often accompanied by a tired feeling.

The use of physostigmine requires some comment concerning the technique and necessary precautions. The dose of the drugs used were determined empirically. The minimal dose required for a man weighing approximately $70 \mathrm{~kg}$ seemed to be I $\mathrm{mg}$. We never went beyond $4 \mathrm{mg}$ in a single test. On the average, $2 \mathrm{mg}$ of physostigmine was used. Physostigmine should not be exposed to light, to avoid degradation. Premedication with metoclopramide prevents nausea and vomiting.

None of the patients complained of loss of erection during the PSC tests. On the contrary, erection was easier to obtain and maintain. Erection was not affected in 60 per cent of the cases when the PSC test was negative, and was improved in 40 per cent. When the PSC test was positive, erection was improved in 80 per cent of the cases. Finally, sexual relations were 'somewhat facilitated' in all the patients performing the test at home.

4. The clinical observations appear to confirm the initial hypothesis. However, hasty conclusions should not be drawn as to the neuropharmacology of ejaculation. 


\section{Conclusions}

Subcutaneous injection of pysostigmine seems to produce results equivalent to those obtained with intrathecal injection of neostigmine but not always with the first trial. The test should therefore be repeated without hesitation.

The indications for both tests are the same: to provoke ejaculation when myelomeres $\mathrm{T}_{12}, \mathrm{~L}_{1}$ and $\mathrm{L}_{2}$ are not damaged by the lesion. When there is doubt about the state of these segments, the test should still be tried as it is innocuous.

The advantage of PSC over ISN, ease of performance and absence of significant side-effects, encouraged us to allow the patients to perform the test at home without surveillance only when three PSC tests were carried out in our clinic without any complication.

We therefore suggest the following schedule:

I. with the patient lying down, fasting for 6-8 hours, and not having received any ganglioplegic therapy.

2. injection of $40 \mathrm{mg}$ of $\mathrm{N}$-butylhyocine bromide is given in a sensitive region of the skin, followed 20 minutes later by $2 \mathrm{mg}$ of physostigmine.

3. masturbation is carried out 20 minutes later.

4. if ejaculation does not occur within 30 minutes, a supplementary injection of I $\mathrm{mg}$ of physostigmine is given.

\section{RÉSUMÉ}

Les auteurs décrivent une thérapeutique nouvelle pour les troubles de l'éjaculation chez le paraplégique.

L'injection sous cutanée de Physostigmine selon certaines modalités et avec certaines précautions a les mêmes indications que l'injection intra rachidienne de Néostigmine: métamères $\mathrm{D}_{1} 2$ à $\mathrm{L} 2$ fonctionnels.

Elle est cependant d'un maniement plus facile que cette dernière et après 3 essais effectués en milieu spécialisé, elle peut être éventuellement appliquée par le paraplégique à son domicile, sans surveillance médicale.

\section{ZUSAMMENFASSUNG}

Die Autoren entdecken eine neue Therapie gegen Ejaculations-schweirigkeiten bei Querschnittsgelaehmten Patienten.

Werden Guewisse Verfahrensweisen beachtet und Spezifische VorsichtsmaBnahmen betroffen, hat die subkutane Injektion von Physiostigmine den gleichen an wenn Dungsbereich wie die Injektion von Neostigmine:Di2-L2 Metameres ins Rückgrat.

Wie ist jedoch leichter durchzuführen als letBtere und nach drei, unter Aufsicht von Fachkrëften erfolgten Versuchen, kann sie eventuell vom patiente selbst ohne arztliche Aufsicht zu Hause durchgeführt werden.

\section{REFERENCES}

Chapelle, P. A. (1978). Valeur sémiologique des syndromes lésionnels cérébrospinal et végétatif; étude critique. Ann. de Méd. Phys., 21, 507-518.

Chapelle, P. A., Colbeau-Justin, Ph., Durand, J. \& Richard, F. (1982). Troubles de l'éjaculation au cours des paraplégies traumatiques. Ann. Urol., 16, 2, 86-92.

Chapelle, P. A., Gaussel, J. J. \& Grossiord, A. (I974). Réflexions concernant les problèmes génito-sexuels des paraplégiques. An. de Méd. Phys. 12, I-28.

François, N., Maury, M, \& JouANNET, P. (I978). L'éléctrostimulation chez le paraplégique. Ann. de Méd. Phys., 21, 418-424.

Grossiord, A., Chapele, P. A. \& LaCERT, PH. (I978). Le segment médullaire lésionnel 
chez le paraplégique. Applications à la fonction génito-sexuelle. Rev. Neurol. Paris, 134, 729-740.

GutTMAN, L. (1949). The effect of prostigmine on the reproductive functions in the spinal man. Proceeding of the 4th Intern. Neurogical Congress. Vol. 2, p. 69, Paris Masson.

Guttmann, L. \& Walsh, J. J. (I97I). Prostigmin assessment test of fertility in spinal man. Parapl. I, 39-50.

Tarabulcy, J. (1972). Sexual function in the normal and in paraplegia. Paraplegia, Io, $201-108$. 